\title{
PERAN DOKTER PENERBANGAN DALAM PELAKSANAAN KEWAJIBAN PEMERIKSAAN KESEHATAN BAGI PENERBANG UNTUK KESELAMATAN PENERBANGAN
}

\author{
Dominiques Reggy Marfilan Tinggogoy, Endang Wahyati Y. dan Johnny Wirgho \\ Dominiques_reggy@yahoo.com \\ Magister Hukum Kesehatan \\ Universitas Katolik Soegijapranata Semarang
}

\begin{abstract}
ABSTRAK
Industri penerbangan dunia berkembang sangat cepat, tidak terkecuali di Indonesia. Dalam keselamatan penerbangan terdapat peran penting dokter penerbangan dalam pelaksanaan kewajiban pemeriksaan kesehatan bagi penerbang. Terciptanya penerbang yang sehat akan mengurangi faktor resiko terjadinya kecelakaan pesawat, dimana faktor yang paling dominan adalah faktor manusia. Penelitian ini meninjau secara yuridis implikasi peran dokter penerbangan dalam pelaksanaan kewajiban pemeriksaan kesehatan bagi penerbang untuk keselamatan penerbangan.

Metode pendekatan yang dipergunakan adalah metode pendekatan yuridis sosiologis berdasarkan Undang-Undang Republik Indonesia Nomor 1 Tahun 2009 Tentang Penerbangan beserta Peraturan Pelaksanaan dari perundang undangan tersebut.

Hasil penelitian ini didapatkan bahwa pengaturan hukum tentang kewajiban pemeriksaan kesehatan bagi penerbang dasar hukumnya Pasal 58 dan Pasal 59 UU Penerbangan, dimana penerbang wajib melakukan pemeriksaan kesehatan, yang merupakan prasyarat penerbang dinyatakan sehat dan dapat menjalankan tugas terbangnya. Peran dokter penerbangan dalam pelaksanaan kewajiban pemeriksaan kesehatan bagi penerbang dasar perannya kewenangan, dimana produk hukumnya berupa sertifikat kesehatan penerbangan, yang diterbitkan oleh Balai Kesehatan Penerbangan. Faktor-faktor yang mempengaruhi peran dokter penerbangan dalam kewajiban pemeriksaan kesehatan bagi penerbang terdiri dari faktor yuridis, dimana beberapa ketentuan tidak terdapat kejelasan sanksi apabila penerbang tidak melakukan kewajiban pemeriksaan kesehatan setiap 6 bulannya sehingga dapat dilanggar dan belum berjalan maksimal, dan faktor teknis berupa SDM yang jumlahnya kurang, belum tersedianya alat-alat medis yang menunjang pemeriksaan, serta faktor pendidikan, dimana dokter penerbangan yang memiliki kewenangan dalam pemeriksaan kesehatan penerbangan yaitu dokter yang telah mengikuti dan lulus dalam pendidikan khusus kedokteran penerbangan. Peran dokter penerbangan dalam keselamatan penerbangan belum berjalan optimal.
\end{abstract}

Kata kunci: Peran, Dokter Penerbangan, Kesehatan Penerbang, Keselamatan Penerbangan 


\section{A. PENDAHULUAN}

Saat ini industri penerbangan dunia berkembang sangat cepat, tidak terkecuali di Indonesia. Di Indonesia perkembangan jumlah perusahaan penerbangan di satu sisi menguntungkan bagi para pengguna jasa transportasi udara karena akan banyak pilihan. Perusahaan-perusahaan tersebut bersaing untuk menarik penumpang sebanyak-banyaknya dengan menawarkan tarif yang lebih murah atau menawarkan berbagai bonus. Namun di sisi lain, dengan tarif yang murah tersebut sering menurunkan kualitas pelayanan (service), bahkan yang lebih mengkhawatirkan lagi adalah akan menyebabkan berkurangnya kualitas pemeliharaan (maintenance) pesawat dan sumber daya manusianya sehingga rawan terhadap keselamatan penerbangan yang dapat berpotensi berakibat pada insiden ataupun accident dalam dunia penerbangan. ${ }^{1}$ Kepercayaan masyarakat atas kenyamanan dan keselamatan dalam penggunaan moda transportasi udara tersebut semakin berkurang ketika baru-baru ini ada beberapa kasus penggunaan narkoba oleh para pilot contohnya tertangkapnya pilot Lion Air, meskipun kebutuhan atas penggunaan jasa penerbangan saat ini sangat tinggi. ${ }^{2}$

Data dari Federal Aviation Association (FAA), badan otonomi penerbangan di Amerika (2009) mengungkapkan, penyebab kecelakaan pesawat terbang karena faktor manusia mencapai $66,7 \%$, faktor media $13,2 \%$, faktor lainnya $20,1 \%{ }^{3}$ Berdasarkan data keselamatan penerbangan International Civil Aviation Organization (ICAO) pada tahun 2011, dimana kejadian accident di dunia selama dekade tahun 2000an, 46\% disebabkan oleh kesalahan penerbang (pilot error). ${ }^{4} \mathrm{Di}$ Indonesia (2011), faktor manusia diperkirakan di atas 50\%. Data lain mengungkapkan kecelakan yang disebabkan pengaruh alkohol sebanyak $4 \% .^{5}$

Regulasi di bidang kesehatan penerbang dalam rangka menjamin keselamatan penerbangan di Indonesia diatur dalam Undang-Undang Nomor 1 Tahun 2009 Tentang Penerbangan (selanjutnya disebut UU Penerbangan) Pasal 59, dimana pelaksanaannya dilakukan oleh pemerintah melalui Balai Kesehatan Penerbangan, yang berada dibawah Direktorat Jenderal Perhubungan Udara Kementerian Perhubungan. Sebagaimana ditentukan dalam UU Penerbangan Pasal 59 bahwa setiap personil penerbangan wajib melakukan pemeriksaan kesehatan secara berkala. ${ }^{6}$ Pelaksanaan pemeriksaan kesehatan bagi penerbang menurut Undang-Undang tersebut dilakukan oleh lembaga yang ditunjuk pemerintah, yaitu Balai Kesehatan Penerbangan. Setelah diadakan pemeriksaan kesehatan lengkap hingga dikeluarkan pernyataan medis, kemudian seorang penerbang akan ditentukan laik atau tidak laik dalam tugas terbangnya, ditandai dengan dikeluarkan sertifikat kesehatan. Sertifikat kesehatan ini berlaku untuk 6 bulan ke depan dan karena itu juga maka pemeriksaan dilakukan setiap 6 bulan sekali. Pemeriksaan ini penting bukan saja untuk mendeteksi resiko penyakit sebelum menjadi suatu bahaya dalam melaksanakan tugas terbang maupun kehidupan sehari-hari, tetapi juga untuk keselamatan bagi para penerbang sebagai salah satu sumber daya dalam perusahaan penerbangan.

\footnotetext{
1 E. Saefullah Wiradipradja. Tanggung Jawab Perusahaan Penerbangan Terhadap Penumpang Menurut Hukum Udara Indonesia. Jurnal Hukum Bisnis Vol.25 No.2, Januari 2006. Jakarta. 2006. h.5-6

2 Abdullah Karim Siregar, Cara Lion Memilih Pilot, Harian Media Indonesia edisi 14 Februari 2012

3 FAA (Federal Aviation Association). Manual of Civil Aviation Medicine. Oklahoma. 2009

4 Igun. Gambaran Keselamatan Penerbangan. http://gloopic.net. diunduh pada 2 April 2012

5 http://tabloidaviasi.com/cakrawala/pentingnya-dokter-penerbangan/ diunduh pada 2 April 2012

6 K. Martono. Hukum Penerbangan: Berdasarkan UU RI No.1 Tahun 2009. CV. Mandar Maju, Bandung. 2009.h.220
} 
Dalam hal keselamatan dunia penerbangan dokter berperan penting dalam kesehatan para penerbang. ${ }^{7}$ Dengan terciptanya para penerbang yang sehat, maka akan mengurangi faktor resiko terjadinya kecelakaan pesawat udara, dimana faktor yang paling dominan dalam kecelakaan ini adalah faktor manusia (salah satunya penerbang), diluar faktor-faktor yang lain seperti cuaca/alam, teknis pesawat, dan faktor kebijakan atau regulasi yang ada. ${ }^{8}$ Para dokter yang bertanggung jawab atas kesehatan para awak pesawat populer dengan sebutan dokter penerbangan. Dokter yang bertugas di sini adalah para dokter yang telah memiliki kualifikasi kedokteran penerbangan dan memiliki sertifikat sebagai "Flight Surgeon". ${ }^{9}$ Di Balai Kesehatan Penerbangan, pemeriksaan terhadap para penerbang dilakukan oleh sejumlah dokter penerbangan. Selanjutnya penerbang yang dipandang telah lulus pemeriksaan akan diberikan sertifikat yang akan berlaku selama enam bulan. Itu artinya isi pernyataan akan kesehatan diberikan oleh dokter-dokter penerbangan yang bekerja di Balai kesehatan Penerbangan.

Berdasarkan hal di atas, peran dokter penerbangan dalam pemeriksaan kesehatan penerbang sangatlah penting, dikarenakan dokter penerbangan dapat menentukan apakah si penerbang layak melaksanakan tugas terbangnya atau tidak setelah dilakukan pemeriksaan kesehatan. Pemeriksaan kesehatan terhadap penerbang merupakan suatu kewajiban yang harus dipenuhi, karena dengan demikian maka akan terjamin bahwa si penerbang memang dalam kondisi yang layak untuk melaksanakan tugas terbangnya, sehingga diharapkan akan berdampak pada terciptanya keselamatan dalam dunia penerbangan.

\section{B. PERUMUSAN MASALAH}

Berdasarkan paparan diatas, maka perumusan masalah yang dapat disimpulkan dalam penelitian ini adalah:

1. Bagaimana pengaturan hukum tentang kewajiban pemeriksaan kesehatan bagi penerbang berdasarkan Undang-Undang Nomor 1 Tahun 2009 tentang Penerbangan?

2. Bagaimana peran dokter penerbangan dalam pelaksanaan kewajiban pemeriksaan kesehatan bagi penerbang untuk keselamatan penerbangan?

3. Faktor-faktor apa sajakah yang mempengaruhi peran dokter penerbangan dalam pelaksanaan kewajiban pemeriksaan kesehatan bagi penerbang?

\section{PEMBAHASAN}

\section{PENGATURAN HUKUM TENTANG KEWAJIBAN PEMERIKSAAN KESEHATAN BAGI PENERBANG BERDASARKAN UNDANG-UNDANG NOMOR 1 TAHUN 2009 TENTANG PENERBANGAN}

Dasar hukum pengaturan tentang kewajiban pemeriksaan kesehatan terhadap penerbang di Indonesia diatur dalam Undang-Undang Republik Indonesia Nomor 1 Tahun 2009 Tentang Penerbangan. Dalam UU Penerbangan ini, beberapa pasal dan ayat yang berkaitan langsung dengan Kesehatan Penerbangan, seperti pada Pasal 58 ayat ketiga butir (b) dimana dapat dianalisis bahwa sehat jasmani dan rohani menjadi salah satu prasyarat bagi setiap personil penerbangan untuk memperoleh sertifikat kompetensi. Berdasarkan penjelasan Pasal 58 ini maka yang berhak menyatakan personil penerbangan dalam kondisi sehat jasmani dan rohani yaitu unit kesehatan yang mempunyai kualifikasi untuk melakukan pemeriksaan kesehatan personil penerbangan. Dengan demikian maka pasal ini mengatur tentang

7 Adi, Asmoro. Ilmu Kesehatan Penerbangan. Pusat Pendidikan \& Pelatihan PT. Garuda Indonesia, Jakarta. 1998.h.3

8 Welly Pakan. Faktor Penyebab Kecelakaan Penerbangan di Indonesia Tahun 2000-2006. Warta Ardhia Vol.34 No.1, Juni 2008. Jakarta. 2008.h.8

9 U.S Naval Flight Surgeon's Manual $3^{\text {rd }}$ ed. Naval Aerospace Medicine Institute, Washington D. C. 1991.h.5 
kesehatan personil penerbangan, termasuk didalamnya penerbang, dimana kesehatan tersebut dinyatakan oleh lembaga yang berkualifikasi melakukan pemeriksaan kesehatan bagi para personil penerbangan. Kata wajib tentu dalam perspektif hukum ada konsekuensinya apabila tidak dilakukan. Kemudian pada Pasal 59 ayat pertama butir (c) menjelaskan kewajiban personil penerbangan untuk melaksanakan pemeriksaan kesehatan secara berkala, yang jangka waktunya disesuaikan dengan kelas dari sertifikat kesehatan yang diajukan. Ketentuan pada Pasal 59 ini berarti mempertegas ketentuan Pasal 58, bahwa untuk memenuhi prasyarat sehat jasmani dan rohani tersebut maka setiap personil pesawat udara, termasuk penerbang, wajib dilakukan pemeriksaan kesehatan secara berkala. Kata wajib tentunya ada konsekuensi hukumnya apabila tidak dilaksanakan.

ICAO (International Civil Aviation Organization) sebagai otoritas penerbangan dunia mengatur tentang kewajiban pemeriksaan kesehatan penerbang ini dalam Manual of Civil Aviation Medicine, Document 8984 Tahun 2008, dimana dasar dari pemeriksaan bertujuan guna mendapatkan sertifikat kesehatan penerbangan berdasarkan kelas masing-masing air crew, yang diatur dalam Annex 1 Chapter 1,2, dan 6. Bentuk pengaturan hukum di Indonesia, dimana Indonesia sebagai negara anggota ICAO wajib meratifikasi aturan-aturan tersebut, yang kemudian dipakai sebagai dasar hukum pelaksanaan pemeriksaan kesehatan penerbang di Indonesia. Peraturan pelaksana dari adanya UU Penerbangan masih mengacu pada ketentuan UU Penerbangan yang lama, belum berdasarkan UU Penerbangan yang baru.

Bentuk ketentuan pengaturan yang terkait dengan pelaksanaan kewajiban pemeriksaan kesehatan bagi penerbang diantaranya Peraturan Pemerintah Nomor 3 Tahun 2001 Tentang Keamanan dan Keselamatan Penerbangan (selanjutnya disebut PP Keamanan dan Keselamatan Penerbangan). PP Keamanan dan Keselamatan Penerbangan mengatur tentang pemberian wewenang pemeriksaan kesehatan penerbangan, yang tercantum pada Pasal 89 ayat pertama, dimana pemeriksaan kesehatan penerbangan diselenggarakan oleh Pemerintah dan pelaksanaannya dapat dilimpahkan kepada badan hukum Indonesia atau perorangan yang mempunyai kualifikasi kesehatan penerbangan.

Keputusan Menteri Perhubungan Nomor: SK.38/OT002/Phb-83 Tentang Organisasi dan Tata Kerja Balai Kesehatan Penerbangan Direktorat Jenderal Perhubungan Udara memuat tentang tugas dan fungsi Balai Kesehatan Penerbangan, yang merupakan lembaga pemerintah yang diberi tugas oleh UU Penerbangan dalam hal pemeriksaan kesehatan penerbang sipil. Hal ini terlihat dalam Pasal 1 ayat pertama, dimana Balai Kesehatan Penerbangan adalah unit pelaksana teknis di bidang kesehatan penerbangan dalam lingkungan Departemen Perhubungan yang berada dibawah dan bertanggungjawab kepada Direktur Jenderal Perhubungan Udara melalui Kepala Direktorat Keselamatan Penerbangan. Pada Pasal 1 ayat kedua dijelaskan bahwa Balai Kesehatan Penerbangan dipimpin oleh seorang Kepala. Kemudian pada Pasal 2 disebutkan bahwa Balai Kesehatan Penerbangan mempunyai tugas melaksanakan pengujian terhadap kesehatan awak pesawat udara dan personil operasi penerbangan, pemeliharaan kesehatan, hygiene dan sanitair dalam bidang kesehatan penerbangan di pelabuhan udara dengan melakukan penelitian di laboratorium.

Untuk menentukan standar kesehatan dan prosedur sertifikasi kesehatan bagi personil penerbangan di Indonesia, ditetapkan Keputusan Menteri Perhubungan dan Telekomunikasi RI Nomor: KM 75 tahun 2000 tentang Civil Aviation Safety Regulation Part 67, Medical Standards and Certification. Isi dari regulasi ini adalah prosedur pemeriksaan kesehatan serta persyaratan-persyaratan bidang kesehatan bagi personil penerbangan di Indonesia yang ditulis dalam bahasa Inggris dan bahasa Indonesia. Keputusan Direktur Jenderal Perhubungan Udara Nomor SKEP/62/V/2004 Tentang Sertifikat Kesehatan Personil Penerbangan mengatur tentang sertifikat kesehatan penerbangan, sebagai tanda lulus uji kesehatan bagi penerbang. Sertifikat kesehatan penerbangan dikeluarkan oleh Balai Kesehatan Penerbangan, dimana jenis sertifikat bagi penerbang diklasifikasikan pada sertifikat kesehatan Kelas Satu, dengan jangka 
waktu berlakunya selama 6 bulan, sehingga setiap jangka waktu 6 bulan sekali, setiap penerbang sipil yang aktif wajib melakukan pemeriksaan kesehatan.

Tujuan dari adanya pengaturan hukum dalam kewajiban pemeriksaan kesehatan penerbang pada akhirnya guna menciptakan keselamatan dalam dunia penerbangan. Tujuan tersebut diidentifikasi dalam:

a. Pengaturan pemeriksaan kesehatan bagi penerbang. Sesuai dengan UU Penerbangan maka perlu diatur beberapa pasal yang terkait pengaturan terhadap kewajiban pemeriksaan kesehatan penerbang ini agar para penerbang sipil tertib dalam menjalankan tugas terbangnya, dimana dengan melakukan pemeriksaan kesehatan maka si penerbang telah menjalankan isi dari UU Penerbangan Pasal 58 dan 59.

b. Pengaturan sertifikat kesehatan penerbangan. Implikasi hukum dari adanya pengaturan tentang kewajiban pemeriksaan kesehatan bagi penerbang berdasarkan UU Penerbangan yaitu setiap penerbang wajib melakukan pemeriksaan kesehatan secara berkala di Balai Kesehatan Penerbangan setiap 6 bulan sekali. Karena ketentuan hukumnya bersifat wajib tentunya ada konsekuensi hukumnya, dimana pada pada Pasal 59 ayat kedua UU Penerbangan dijelaskan bahwa sanksi bagi personil pesawat udara yang melanggar ketentuan ini yaitu berupa:

1) peringatan;

2) pembekuan lisensi; dan/atau

3) pencabutan lisensi.

Berdasarkan ketentuan Pasal 58 UU Penerbangan dapat dianalisis bahwa sehat jasmani dan rohani menjadi salah satu prasyarat bagi setiap personil penerbangan untuk memperoleh sertifikat kompetensi. Pasal ini menjadi pengesahan bahwa Balai Kesehatan Penerbangan merupakan lembaga kesehatan yang mempunyai kualifikasi melakukan pemeriksaan kesehatan personil penerbangan, sehingga Balai Kesehatan Penerbangan berhak menyatakan personil penerbangan tersebut dinyatakan sehat jasmani dan rohani berdasarkan hasil pemeriksaan kesehatan. Namun demikian berdasarkan hasil penelitian, konsekuensi hukum apabila si penerbang tidak melakukan pemeriksaan pada bulan ke 6 berikutnya belum jelas diatur. Dalam praktiknya apabila pemeriksaan kesehatan ini tidak dilaksanakan, maka si penerbang hanya tidak dapat menjalankan tugas terbangnya sampai penerbang tersebut melakukan pemeriksaaan kesehatan kembali dan dinyatakan fit untuk menjalankan tugas terbangnya.

\section{PERAN DOKTER PENERBANGAN DALAM PELAKSANAAN KEWAJIBAN PEMERIKSAAN KESEHATAN BAGI PENERBANG UNTUK KESELAMATAN PENERBANGAN}

Dasar hukum dari peran dokter penerbangan di Indonesia dalam pelaksanaan kewajiban pemeriksaan kesehatan bagi penerbang diatur dalam Undang-Undang Republik Indonesia Nomor 29 Tahun 2004 Tentang Praktik Kedokteran (selanjutnya disebut UU Praktik Kedokteran). Hubungan dokter pasien dimulai pada saat pasien meminta dokter untuk mengobatinya dan si dokter menerimanya. ${ }^{10}$ Pasien adalah setiap orang yang melakukan konsultasi masalah kesehatannya untuk memperoleh pelayanan kesehatan yang diperlukan baik secara langsung kepada dokter atau dokter gigi. ${ }^{11}$ Menurut Wila Chandrawila Supriadi (2001), pasien adalah orang sakit yang membutuhkan pertolongan dokter untuk menyembuhkan penyakit yang dideritanya. ${ }^{12}$ Dengan demikian antara dokter dengan pasiennya terdapat suatu hubungan, yang dikenal dengan transaksi terapeutik (perjanjian

10 J. Guwandi. Dokter, Pasien, dan Hukum. Fakultas kedokteran Universitas Indonesia, Jakarta. 2007.h.23

11 Titik Triwulan, Shita Febriana. Perlindungan Hukum Bagi Pasien. Prestasi Pustaka, Jakarta. 2010.h.21

12 Wila Chandrawila Supriadi. Hukum Kedokteran. Mandar Maju, Bandung. 2001.h.20 
terapeutik). Dokter dan pasien adalah dua subyek hukum yang terkait dalam hukum kedokteran, dimana dokter sebagai pemberi pelayanan medik dan pasien sebagai penerima pelayanan medik. Hak dan kewajiban dalam hubungan dokter pasien pada pelayanan kesehatan diatur dalam UU Praktik Kedokteran, dimana dokter penerbangan dalam perannya sebagai pemeriksa kesehatan bagi penerbang dalam praktiknya di Balai Kesehatan Penerbangan mengacu pada UU Praktik Kedokteran ini. Menurut Pasal 50 UU Praktik Kedokteran, dokter penerbangan dalam upaya pelayanan kesehatan berhak menjalankan tugas profesionalnya dalam memeriksa kesehatan penerbang sesuai dengan standar profesi dan standar prosedur operasional yang ada. Standar operasional yang ada mengacu pada Keputusan Menteri Perhubungan dan Telekomunikasi RI Nomor: KM.75 Tahun 2000 tentang Civil Aviation Safety Regulation Part 67, Medical Standards and Certification.

Dokter penerbangan pun memiliki beberapa kewajiban dalam menjalankan profesinya sebagai dokter. Kewajiban-kewajiban diatur dalam Pasal 51 UU Praktik Kedokteran, dimana dokter penerbangan wajib memberikan pelayanan medis sesuai dengan standar profesi dan standar prosedur operasional yang ada. Pelayanan medis yang dilakukan berupa pemeriksaan kesehatan penerbang, akan tetapi bagi penerbang yang belum dinyatakan fit untuk menjalankan tugas terbangnya, maka dokter penerbangan akan memberikan pengobatan sesuai dengan kebutuhan medis penerbang tersebut, ataupun merujuk ke dokter spesialis yang terkait. Kemudian setelah penerbang tersebut selesai menjalankan pengobatannya, baru akan dilakukan pemeriksaan kesehatan kembali.

Penerbang dalam perannya sebagai pasien pada pemeriksaan kesehatan juga memiliki hak dan kewajiban sebagai pasien. Hak pasien seperti yang diatur dalam Pasal 52 UU Praktik Kedokteran, dimana penerbang berhak mendapatkan keterangan dari hasil pemeriksaan kesehatan yang dilakukan, berupa lembar confidential, yang berisi catatan hasil evaluasi dan catatan singkat rekam medis pasien. Pemeriksaan kesehatan yang dilakukan terhadap penerbang harus sesuai standar kompetensi dan standar operasional yang ada. Bagi penerbang yang tidak dinyatakan fit dan perlu dilakukan tindakan khusus oleh dokter spesialis, dalam hal ini dokter penerbangan akan melakukan rujukan, maka penerbang berhak untuk menolak tindakan medis yang dianjurkan oleh dokter penerbangan, walaupun dengan konsekuensi penerbang tersebut akan dinyatakan unfit dan tidak dapat menjalankan tugas terbangnya. Adapun kewajiban-kewajiban penerbang sebagai pasien diatur dalam Pasal 53 UU Praktik Kedokteran, dimana menurut ketentuan tersebut disebutkan bahwa penerbang dalam menerima pelayanan kesehatan berkewajiban untuk memberikan informasi yang lengkap dan jujur tentang masalah kesehatannya, serta mematuhi petunjuk yang diberikan oleh dokter penerbangan. Penerbang juga berkewajiban memberikan imbalan berupa pembayaran atas jasa pemeriksaan kesehatan yang dilakukan.

Undang-Undang Republik Indonesia Nomor 36 Tahun 2009 Tentang Kesehatan (selanjutnya disebut UU Kesehatan) juga menjadi dasar hukum bagi peran dokter penerbangan dalam kewajiban pemeriksaan kesehatan bagi penerbang sangat penting. Hal ini sejalan dengan tujuan pemeriksaan kesehatan bagi penerbang, yang dapat dikategorikan dalam upaya kesehatan yang dilaksanakan oleh pemerintah di dalam dunia kedokteran penerbangan sebagai upaya preventif, sesuai dengan UU Kesehatan Pasal 1 ayat kesebelas dimana disebutkan bahwa upaya kesehatan merupakan kegiatan dan/atau serangkaian kegiatan yang dilakukan secara terpadu, terintegrasi dan berkesinambungan untuk memelihara dan meningkatkan derajat kesehatan masyarakat dalam bentuk pencegahan penyakit, peningkatan kesehatan, pengobatan penyakit, dan pemulihan kesehatan oleh pemerintah dan/atau masyarakat. 
Pasal 22 ayat pertama UU Kesehatan menyebutkan bahwa tenaga kesehatan harus memiliki kualifikasi minimum. Terkait dengan pasal ini, maka dokter penerbangan yang berhak melakukan pemeriksaan kesehatan terhadap penerbang yaitu dokter yang telah memiliki kualifikasi sebagai Flight Surgeon, sedangkan berdasarkan Pasal 23 UU Kesehatan, dokter penerbangan memiliki kewenangan untuk melakukan pemeriksaan kesehatan bagi penerbang, dalam hal ini limpahan kewenangan diperoleh dari Kepala Balai Kesehatan Penerbangan mewakili Balai Kesehatan Penerbangan.

Bentuk ketentuan pelaksana yang terkait dengan peran dokter penerbangan dalam pelaksanaan kewajiban pemeriksaan kesehatan bagi penerbang diantaranya yaitu Peraturan Direktur Jenderal Perhubungan Udara Nomor: SKEP/131/VII/2007 tentang Perubahan Atas Keputusan Direktur Jenderal Perhubungan Udara Nomor: SKEP/62/V/2004 tentang Sertifikat Kesehatan Personil Penerbangan. Peran dokter penerbangan dalam Peraturan Direktur Jenderal Perhubungan Udara ini berupa limpahan wewenang untuk pemeriksaan kesehatan dari Direktur Jenderal Perhubungan Udara kepada dokter penerbangan atau Flight Surgeon yang ditunjuk. Hal ini seperti terlihat pada Pasal 2, dimana setiap personil penerbangan wajib memiliki sertifikat kesehatan yang ditandatangani oleh dokter penerbangan yang ditunjuk oleh Kepala Balai Kesehatan Penerbangan atas nama Direktur Jenderal. Akan tetapi dokter penerbangan tidak menjamin kepastian dan perlindungan hukum, karena terkait peraturan keselamatan penerbangan di Indonesia, tidak satu pun ketentuan hukum yang mengatur secara khusus tentang dokter penerbangan. Dokter penerbangan menurut ICAO (International Civil Aviation Organization) dalam Manual of Civil Aviation Medicine yaitu dokter yang telah mengikuti dan lulus dalam pendidikan khusus kedokteran penerbangan. Dokter penerbangan akan menandatangani sertifikat kesehatan kelas satu bagi penerbang yang berlaku selama 6 bulan, dimana sertifikat tersebut harus diperbarui sesuai jangka waktu berlakunya apabila penerbang tetap ingin menjalankan tugas terbangnya.

Keputusan Kepala Balai Kesehatan Penerbangan Nomor 254/HATPEN/SKEP/XII/2011 Tentang Penunjukan Dokter Spesialis Kesehatan Penerbangan, Dokter Umum (Flight Surgeon) Dan Dokter Umum Sebagai Penandatangan Sertifikat Kesehatan (Medical Certificate) berisi limpahan kewenangan dari Kepala Balai Kesehatan Penerbangan sebagai pemimpin dan penerima mandat dari Direktur Jenderal Perhubungan Udara kepada dokter penerbangan yang bekerja di Balai Kesehatan Penerbangan dalam menandatangani sertifikat kesehatan, maka dokter penerbangan yang menandatangani sertifikat kesehatan kelas Satu dan Dua merupakan dokter penerbangan yang sudah mempunyai kualifikasi Flight Surgeon, sedangkan untuk kelas Tiga dokter penerbangan biasa. Kemudian dijelaskan pada Pasal 3 ayat pertama, dimana dokter penerbangan atau Flight Surgeon sebagai penandatangan surat sertifikasi kesehatan (Medical Certificate), mempunyai tugas dan tanggung jawab melakukan pengujian kesehatan terhadap awak pesawat udara dan personil penerbangan lainnya. Akan tetapi kelemahan dari ketentuan ini tidak dijelaskan mengenai definisi Dokter Spesialis Kesehatan Penerbangan, Dokter Umum (Flight Surgeon) Dan Dokter Umum Sebagai Penandatangan Sertifikat Kesehatan (Medical Certificate), walaupun dalam praktiknya ketentuan ini tetap dijalankan.

Tujuan dari pengaturan peran dokter penerbangan dalam pemeriksaaan kesehatan bagi penerbang yaitu sebagai pelaksana "jabatan" atau pelaksana kewenangan profesional guna menyatakan bahwa secara kesehatan penerbang tersebut fit untuk menjalankan tugasnya sebagai penerbang, yang ditandai dengan terbitnya sertifikat kesehatan bagi penerbang tersebut. Peran dokter penerbangan dalam menjalankan tugas sebagai pemeriksa kesehatan bagi penerbang di Balai Kesehatan Penerbangan sebagai upaya kesehatan yang bersifat preventif, dalam hal ini masalah kesehatannya bersifat seputar dunia kedokteran dalam penerbangan. Kedudukan dokter penerbangan dalam pelaksanaan kewajiban pemeriksaan kesehatan yaitu sebagai pelaksana tugas unit teknis yang mempunyai kualifikasi 
dalam pemeriksaan kesehatan personil penerbangan, dalam hal ini Balai Kesehatan Penerbangan, termasuk yang diperiksa adalah penerbang.

Mekanisme pelaksanaan peran dokter penerbangan, khususnya dokter penerbangan di Balai Kesehatan Penerbangan terjadi pada tahap pemeriksaan fisik dan evaluasi hasil pemeriksaan kesehatan penerbang, dimana kemudian diputuskan apakah penerbang tersebut hasil pemeriksaannya baik dan laik untuk melaksanakan tugas terbangnya. Hasil dari pemeriksaan kesehatan yaitu berupa sertifikat kesehatan yang akan dikeluarkan bagi penerbang tersebut. Apabila hasil pemeriksaannya baik, maka akan dikeluarkan sertifikat kesehatan bagi penerbang, kemudian apabila hasil pemeriksaan kurang baik, maka sertifikat kesehatan tidak akan dikeluarkan, penerbang akan diberikan istirahat untuk kemudian diberikan kesempatan melakukan pemeriksaan kesehatan ulang di kemudian hari, ataupun dikonsulkan kepada dokter spesialis apabila diperlukan, terkait dengan penyakit atau permasalahan yang dihadapi oleh penerbang tersebut. Apabila dalam pemeriksaan kesehatan ulang penerbang tersebut hasilnya baik, ataupun hasil konsulnya menyatakan tidak ada kelainan dan tidak akan mengganggu pekerjaan penerbang tersebut, maka sertifikat kesehatan akan dikeluarkan bagi penerbang tersebut. Apabila hasil konsul dinyatakan penerbang tersebut harus beristirahat sambil melaksanakan terapi untuk penyembuhan penyakitnya, maka akan dikeluarkan surat unfit, sampai penerbang tersebut dinyatakan telah sembuh dari penyakitnya dan melakukan pemeriksaan kesehatan ulangan dengan hasil yang baik.

Implikasi peran dokter penerbangan terhadap keselamatan penerbangan yaitu dokter penerbangan dari sisi pelaksanaan profesinya telah melakukan pelayanan kesehatan terhadap para penerbang, sifat perbuatannya adalah upaya pelayanan kesehatan yang meliputi pemeriksaan fisik, mata, audiometri, gigi, paru-paru, jantung, treadmil, ECG, dan beberapa uji kesehatan lainnya, dimana hasilnya kemudian direkapitulasi dan dievaluasi, untuk kemudian ditentukan apakah penerbang tersebut dapat dinyatakan fit atau tidak (unfit), berupa terbitnya sertifikat kesehatan penerbangan kelas satu. Dari aspek keselamatan penerbangan, bahwa peran dokter penerbangan merupakan sarana preventif, dalam rangka upaya pencegahan terjadinya insiden ataupun accident di dunia penerbangan. Dari sisi hukum, peran dokter penerbangan dapat mencegah terjadinya perbuatan melanggar Undang-Undang, dimana para penerbang wajib melaksanakan pemeriksaan kesehatan sebelum menjalankan tugas terbangnya.

\section{FAKTOR-FAKTOR YANG MEMPENGARUHI PERAN DOKTER PENERBANGAN DALAM PELAKSANAAN KEWAJIBAN PEMERIKSAAAN KESEHATAN BAGI PENERBANG}

Dunia penerbangan yang berkembang cepat menuntut keselamatan penerbangan yang lebih baik, dimana salah satu kuncinya yaitu dokter penerbangan yang berperan dalam kesehatan para penerbang. Dengan terciptanya para penerbang yang sehat, maka akan mengurangi faktor resiko terjadinya kecelakaan pesawat udara, dimana faktor yang paling dominan dalam kecelakaan ini adalah faktor manusia (salah satunya penerbang), diluar faktorfaktor yang lainnya.

Berdasarkan uraian di atas, maka dokter penerbangan memiliki peran dalam kewajiban pemeriksaan kesehatan bagi penerbang. Adapun faktor-faktor yang mempengaruhi peran dokter penerbangan dalam pelaksanaan kewajiban pemeriksaan kesehatan bagi penerbang yaitu sebagai berikut:

\section{a. Faktor Yuridis}

Faktor yuridis yang mempengaruhi peran dokter penerbangan dalam pelaksanaan kewajiban pemeriksaan kesehatan bagi penerbang yaitu: 
1) Dalam UU Penerbangan pasal yang mengatur tentang kesehatan penerbangan hanya terdiri dari beberapa pasal saja, hal ini diikuti dengan adanya ketidakjelasan mengenai sanksi hukumnya, sehingga menyebabkan penerbang tidak wajib melakukan pemeriksaan kesehatan setiap 6 bulannya. Belum ada. Pengaturan tentang apabila penerbang tidak melakukan kewajiban pemeriksaan kesehatan maka penerbang tersebut, maka penerbang tidak dapat menjalankan tugas terbangnya, dan bila tidak memenuhi syarat kesehatan maka tidak akan dikeluarkan sertifikat kesehatan penerbangan, dimana aturan hukum yang menjelaskan hal ini belum ada.

2) Dalam PP Keamanan dan Keselamatan Penerbangan juga sama halnya dengan UU Penerbangan, dimana pada PP ini hanya diatur mengenai kewajiban pemeriksaan kesehatan bagi penerbang tanpa menyebutkan sanksinya.

\section{b. Faktor Teknis}

Faktor teknis yang mempengaruhi peran dokter penerbangan dalam pemeriksaan pelaksanaan pemeriksaan kesehatan bagi penerbang terlihat dlam implementasi beberapa kasus berikut, yaitu:

1) Faktor Sumber Daya Manusia (SDM)

Tenaga SDM dokter penerbangan yang berjumlah 14 orang belum sebanding dengan jumlah penerbang yang terdaftar aktif saat ini sekitar 60ooan orang (Buku Register Balai Kesehatan Penerbangan), sehingga mengakibatkan pencapaian hasil pemeriksaan kesehatan bagi penerbang yang baik belum berjalan secara optimal.

2) Faktor Kelengkapan Alat-Alat Medis

Kelengkapan alat-alat medis sangat mendukung peran dokter penerbangan dalam keselamatan penerbangan. Belum tersedianya alat-alat medis yang menunjang pemeriksaan menyebabkan beberapa pemeriksaan belum dapat dilakukan.

3) Faktor Pendidikan

Dokter penerbangan yang memiliki kewenangan dalam pemeriksaan kesehatan penerbangan yaitu dokter yang telah mengikuti dan lulus dalam pendidikan khusus kedokteran penerbangan atau Flight Surgeon. Dokter penerbangan memiliki kewenangan dalam memeriksa, menentukan diagnosa, serta evaluasi hasil dari pemeriksaan kesehatan penerbang. Produk hukum dari kewenangan ini berupa sertifikat kesehatan penerbangan.

\section{PENUTUP}

\section{KESIMPULAN}

Dari uraian di atas ini, beberapa hal yang dapat ditarik sebagai kesimpulan dari pembahasan Peran Dokter Penerbangan Dalam Pelaksanaan Kewajiban Pemeriksaan Kesehatan Bagi Penerbang Untuk Keselamatan Penerbangan, adalah sebagai berikut:

a. Pengaturan hukum tentang kewajiban pemeriksaan kesehatan bagi penerbang dasar hukumnya yaitu Pasal 58 dan Pasal 59 UU Penerbangan, dimana penerbang wajib melakukan pemeriksaan kesehatan sebelum melaksanakan tugas terbangnya, serta wajib dalam kondisi sehat jasmani dan rohani selama menjalankan tugas terbangnya. Pemeriksaan kesehatan merupakan prasyarat untuk penerbang dinyatakan sehat, bila tidak dilakukan pemeriksaan kesehatan maka penerbang tidak dapat menjalankan tugas terbangnya, dan bila tidak memenuhi syarat kesehatan maka tidak akan dikeluarkan sertifikat kesehatan penerbangan. 
b. Peran dokter penerbangan dalam pelaksanaan kewajiban pemeriksaan kesehatan bagi penerbang yaitu dasar perannya kewenangan, dimana syarat untuk mendapatkan kewenangan tersebut sebagai prasyarat maka seorang dokter harus telah mengikuti dan lulus dalam pendidikan khusus kedokteran penerbangan atau Flight Surgeon. Dokter penerbangan memiliki kewenangan dalam memeriksa, menentukan diagnosa, serta evaluasi hasil dari pemeriksaan kesehatan penerbang, dimana produk hukumnya berupa sertifikat kesehatan penerbangan. Sertifikat kesehatan penerbangan diterbitkan oleh Balai Kesehatan Penerbangan, dokter penerbangan bertugas berdasarkan limpahan kewenangan dari Kepala Balai Kesehatan Penerbangan atas nama Balai Kesehatan Penerbangan. Akan tetapi dokter penerbangan tidak menjamin kepastian dan perlindungan hukum, karena terkait peraturan keselamatan penerbangan di Indonesia, tidak satu pun ketentuan hukum yang mengatur secara khusus tentang dokter penerbangan.

c. Faktor-faktor yang mempengaruhi peran dokter penerbangan dalam pelaksanaan kewajiban pemeriksaan kesehatan bagi penerbang terdiri dari faktor yuridis dan faktor teknis berupa SDM, kelengkapan alat-alat medis dan pendidikan. Faktor yuridis yang masih terdapat kelemahan dimana pengaturan tentang apabila penerbang tidak melakukan kewajiban pemeriksaan kesehatan, maka penerbang tidak dapat menjalankan tugas terbangnya, dan bila tidak memenuhi syarat kesehatan maka tidak akan dikeluarkan sertifikat kesehatan penerbangan, aturan hukum yang menjelaskan hal ini belum ada. Faktor teknis berupa SDM, dimana dokter penerbangan yang kurang, sehingga mengakibatkan pencapaian hasil pemeriksaan kesehatan bagi penerbang yang baik belum berjalan secara optimal. Belum tersedianya alat-alat medis yang menunjang pemeriksaan menyebabkan beberapa pemeriksaan belum dapat dilakukan. Kemudian faktor pendidikan, dimana dokter penerbangan yang memiliki kewenangan dalam pemeriksaan kesehatan penerbangan yaitu dokter yang telah mengikuti dan lulus dalam pendidikan khusus kedokteran penerbangan atau Flight Surgeon. Produk hukum dari kewenangan ini berupa sertifikat kesehatan penerbangan.

\section{SARAN}

Saran yang dapat diberikan dari pembahasan penelitian ini, yaitu:

1. Bagi Direktorat Jenderal Perhubungan Udara

a. Meninjau kembali aturan-aturan hukum yang terkait tentang pemeriksaan kesehatan bagi penerbang apakah masih relevan untuk diberlakukan atau tidak dengan pemberlakuannya Undang-Undang Nomor 1 Tahun 2009 Tentang Penerbangan.

b. Membuat ketentuan hukum yang mengatur secara khusus tentang dokter penerbangan.

2. Bagi Balai Kesehatan Penerbangan

a. Menambah jumlah dokter penerbangan pada Balai Kesehatan Penerbangan.

b. Mengeluarkan peraturan atau keputusan yang mewajibkan agar setiap perusahaan penerbangan mempunyai dokter penerbangan untuk menerima pendelegasian wewenang dalam pengawasan kesehatan penerbang di lapangan termasuk penerbang dengan kasus medical flexibility.

c. Membuat formulir sertifikat kesehatan penerbangan sebagai hasil pemeriksaan sesuai ketentuan yang ada.

3. Bagi Dokter Penerbangan 
Meningkatkan perannya dalam menjalankan tugas sebagai pemeriksa terhadap kesehatan penerbang sesuai dengan ketentuan yang ada guna menunjang keselamatan penerbangan.

4. Bagi Penerbang

a. Selalu menjaga kesehatan dalam menjalankan tugas terbangnya serta melaksanakan pemeriksaan kesehatan secara berkala sesuai ketentuan yang ada

b. Melaporkan kepada Balai Kesehatan Penerbangan apabila penerbang mengalami gangguan atau penurunan kesehatan, yang dianggap dapat menggangu tugas terbangnya.

\section{DAFTAR PUSTAKA}

\section{A. BUKU}

Adi Asmoro. Ilmu Kesehatan Penerbangan. Pusat Pendidikan \& Pelatihan PT. Garuda Indonesia, Jakarta. 1998.

Balai Kesehatan Penerbangan. Profil dan Rencana Strategis Balai Kesehatan Penerbangan 20102014. Direktorat Jenderal Perhubungan Udara Kementerian Perhubungan, Jakarta. 2009.

Evans, Anthony D.B. International Regulation of Medical Standards, in Ernsting's Aviation Medicine $4^{\text {th }}$ ed., Hodder Arnold (Publishers) Ltd, New York. 2006.

FAA (Federal Aviation Association). Manual of Civil Aviation Medicine, Oklahoma. 2009.

ICAO (International Civil Aviation Organization). Manual of Civil Aviation Medicine, Montreal. 2008.

J. Guwandi. Dokter, Pasien, dan Hukum. Fakultas kedokteran Universitas Indonesia, Jakarta. 2007.

K. Martono. Hukum Penerbangan: Berdasarkan UURI No.1 Tahun 2009. CV. Mandar Maju, Bandung. 2009.

Samsi Jacobalis. Pengantar Tentang Perkembangan Ilmu Kedokteran, Etika Medis dan Bioetika. Sagung Seto bekerjasama dengan Universitas Tarumanegara, Jakarta. 2005.

Titik Triwulan, Shita Febriana. Perlindungan Hukum Bagi Pasien. Prestasi Pustaka, Jakarta. 2010.

U. S Naval Flight Surgeon's Manual $3^{\text {rd }}$ ed. Naval Aerospace Medicine Institute, Washington D. C. 1991.

Wila Chandrawila Supriadi. Hukum Kedokteran. Mandar Maju, Bandung. 2001.

\section{B. PERATURAN PERUNDANG-UNDANGAN NASIONAL DAN INTERNASIONAL}

ICAO (International Civil Aviation Organization) Annex 1, Amandement 167

Undang-Undang Dasar Republik Indonesia Tahun 1945

Undang-Undang Republik Indonesia Nomor 29 Tahun 2004 Tentang Praktik Kedokteran

Undang-Undang Republik Indonesia Nomor 1 Tahun 2009 Tentang Penerbangan

Undang-Undang Republik Indonesia Nomor 36 Tahun 2009 Tentang Kesehatan

Peraturan Pemerintah RI No 3 Tahun 2001 tentang Keamanan dan Keselamatan Penerbangan

Keputusan Menteri Perhubungan Nomor: SK 38/OT 002/ Phb-83 tentang Organisasi dan Tata Kerja Balai Kesehatan Penerbangan Direktorat Jenderal Perhubungan Udara 
Keputusan Menteri Perhubungan dan Telekomunikasi RI Nomor: KM 75 Tahun 2000 tentang Civil Aviation Safety Regulation Part 67, Medical Standards and Certification

Keputusan Direktur Jenderal Perhubungan Udara Nomor: SKEP/62/V/2004 tentang Sertifikat Kesehatan Personil Penerbangan

Peraturan Direktur Jenderal Perhubungan Udara Nomor: SKEP/131/VII/2007 tentang Perubahan Atas Keputusan Direktur Jenderal Perhubungan Udara Nomor: SKEP/62/V/2004 tentang Sertifikat Kesehatan Personil Penerbangan

Keputusan Kepala Balai Kesehatan Penerbangan Nomor 254/HATPEN/SKEP/XII/2011 Tentang Penunjukan Dokter Spesialis Kesehatan Penerbangan, Dokter Umum (Flight Surgeon) Dan Dokter Umum Sebagai Penandatangan Sertifikat Kesehatan (Medical Certificate)

\section{JURNAL DAN KARYA ILMIAH}

E. Saefullah Wiradipradja. Tanggung Jawab Perusahaan Penerbangan Terhadap Penumpang Menurut Hukum Udara Indonesia. Jurnal Hukum Bisnis Vol.25 No.2, Januari 2006. Jakarta. 2006.

Welly Pakan. Faktor Penyebab Kecelakaan Penerbangan di Indonesia Tahun 2000-2006. Warta Ardhia Vol.34 No.1, Juni 2008. Jakarta. 2008.

\section{INTERNET DAN SURAT KABAR}

Igun. Gambaran Keselamatan Penerbangan. http://gloopic.net, diunduh pada 2 April 2012

http://tabloidaviasi.com/cakrawala/pentingnya-dokterpenerbangan,diunduh pada 29 Maret 2012

Abdullah Karim Siregar, Cara Lion Memilih Pilot, Harian Media Indonesia edisi 14 Februari 2012 